\title{
THE EDUCATION OF YOUNG ORANG-UTANS TO LIVING IN THE WILD
}

\author{
November, 1961, to February, 1963 \\ By Barbara Harrisson
}

\section{INTRODUCTION}

An experimental research project is being carried out at Bako National Park in Sarawak to devise means by which young orphaned orang-utans can be re-established to wild living.

The experiment would not have been feasible without the devotion of three local officers, two Land Dayaks and one Malay. The senior officer, Bidai anak Penghulu Nimbun, particularly, contributed through his year's previous experience and intimate understanding of the animals-he became their acknowledged tutor. This relationship was essential because the young orang-utans released at Bako are without the chance of contact with wild adults.

Sympathetic guidance and understanding came from $\mathrm{Mr}$. Tom Harrisson, Curator of the Sarawak Museum; encouraging support from Mr. B. E. Smythies, Conservator of Forests, Sarawak, and Chief Game Warden. The Sarawak Government assisted with special funds; so did the World Wildlife Fund and the Wenner-Gran Foundation. The authorities and staff of the Bako National Park under Dr. J. A. R. Anderson and Mr. Abang Muss are helping the project with patient understanding. The Forest Botanist, Dr. P. S. Ashton, kindly identified botanical specimens of natural foods taken spontaneously by the orangs at Bako.

\section{Background.}

Research into the numerical status of wild orang-utans in scattered habitat areas of Sarawak supported both locally ${ }^{1}$ and from outside ${ }^{2}$ has shown a deplorable situation. The animal, in spite of rigid protection laws during recent years, remains threatened with extinction. In Indonesia the situation is particularly distressing owing to lack of control. Frequent smuggling of captured babies across the Straits to Singapore persists.

The increased demand by zoos of the Western world has steadily encouraged illegal trade of orang babies, and it remains a lucrative business in Sumatra and Borneo to kill a mother in order to obtain her offspring. Whereas an estimated half of these youngsters die or become mortally sick before they even reach a zoo, the remainder will only spend an average of four years in captivity. Very few captives grow up to reach maturity, even under good zoo care. Still fewer breed in zoos. ${ }^{3}$

The normal zoo facilities, even including cages without bars, do not suit the mentality of the Great Apes. This is specially so in the case of the orang-utan which is adapted to a life in trees and to roaming large jungle territories. Young growing animals particularly suffer under zoo conditions which do not give-and cannot give for lack of space-the facilities needed to ensure normal physical and mental development. The usual 
result is lethargic, sometimes overfed creatures, with all the signs of psychoses and neuroses evident in human beings confined for long years in prisons. One recent critic puts this sad fact into no-nonsense perspective :-

"It is highly questionable whether the import of orangs, or any other threatened species, should be allowed into civilized countries. There is no justification on scientific grounds because it is now cheaper and easier to transport the biologist to the ape than vice versa. The real irony of the situation is that these orangs acquired at so much cost are then kept in such a way as to make them useless as entertainment or for research." 4

Support and protection of the remaining populations of wild orang-utans must be sought by the Governments concerned in the creation of Wild Life and Nature Reserves of reasonable size. The minimum requirement for a reserve population of 300 orang-utans would be about 600 square miles of territory. ${ }^{5}$ Strict control by protection laws is required as a matter of course, both within habitat areas and along trade routes and entrepots. It is equally important to acquire better knowledge of the natural life of this animal because, when we know more about these close cousins of ours, we may discover other and more effective measures to preserve the remaining wild populations in restricted habitat areas.

So far little is known about the ecology and behaviour of the wild orang, mainly because of the overwhelming difficulties of observing and keeping in touch with these tree-born creatures, which roam wide distances and live in small, scattered family units.

\section{The Purpose of the Project}

The aim of the Bako Project is firstly to devise ways in which young orphaned orang-utans can be re-established to wild living and selfsufficiency in a closely protected jungle area. Thereby it may be possible to save orangs which are rescued from illegal captivity, or which are obtained accidentally, and to re-introduce them into Game Reserves or National Parks that already include wild orang-utans. The second purpose is to observe closely the young orphans under semi-wild conditions and thus contribute to the knowledge and understanding of the species.

Bako Park is not ideal for the project. First, it does not contain a wild population of orang-utans, which would probably stimulate and accelerate the progress of orphaned youngsters. Secondly, the available areas of high, primary forest are restricted. ${ }^{6}$ Bako could never support more than about six individual orang-utans if they were to live there, wild. Thirdly, there are conflicting human interests. The park, owing to its easy accessibility from Kuching, particularly during the summer months from April to September, is extensively used by holiday visitors.

This is unfortunate from the tame orang's point of view as one of the main difficulties of the growing youngster is to recognize and acknowledge the inferiority of human physical strength and arboreal ability, while at the same time remaining under human rather than apean tutorship.

Similarly, the animals themselves for which the project is at present functioning, are not an ideal social group. 


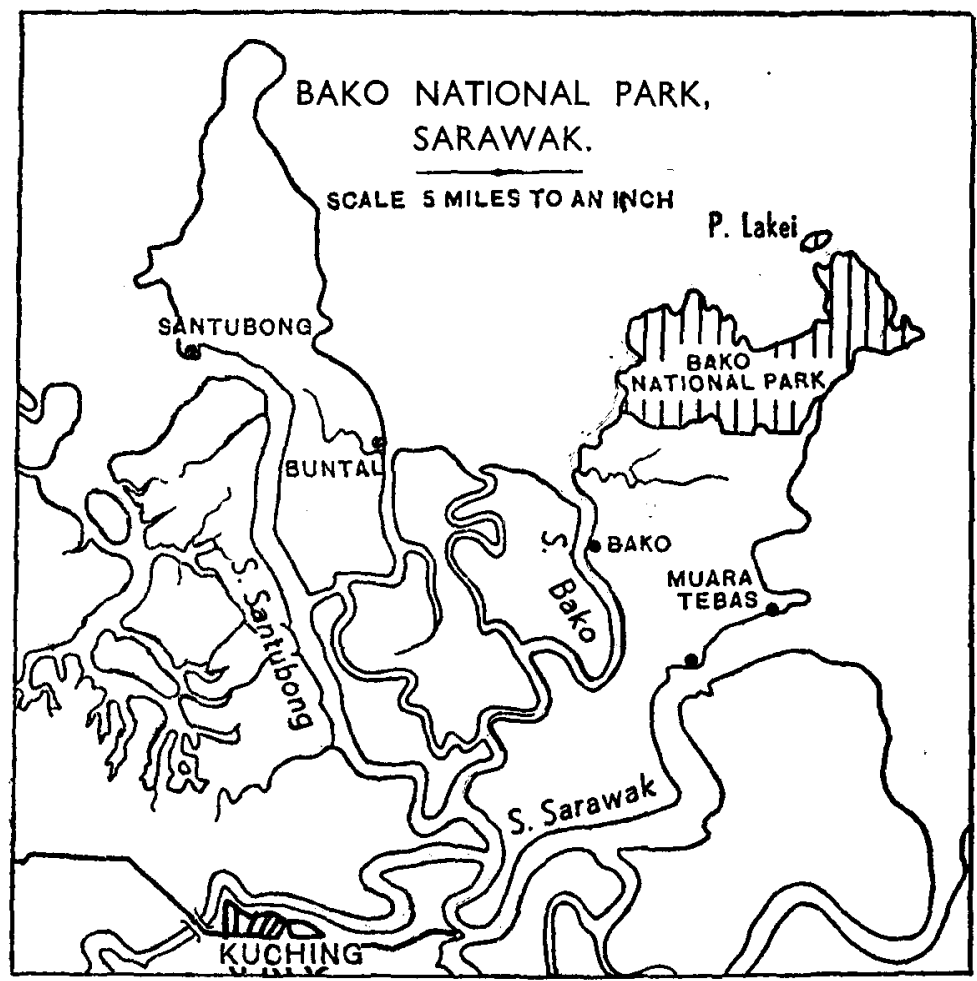

On the other hand, accessibility was an important requirement, at least during the first stages of the project, owing to the need for constant close supervision and for regular supplies of fresh fruit. This, coupled with the fact that Bako Park was the only national park in all Borneo in 1961, made the choice inevitable.

\section{Resources and Organization}

Budget.-The project is run on a shoe-string budget. Capital expenditure (erection of enclosure, camp and equipment at Bako Park) from June to December, 1962, was roughly $\$$ (Straits) 3,000 ( $£ 500)$. Expenses on personnel (three attendants), services (transport) and food, average $\$$ (Straits) $725(£ 90)$ per month. This, however, takes Sarawak Government support for granted in numerous ways, through Forest Department and Sarawak Museum assistance. If the project were run as a separate unit without such support, expenses might easily double.

Personnel.-Three attendants are permanently employed on the project on a rota. That is, one attendant is on duty at Bako for two months running, then on relief duty within the Sarawak Museum at Kuching for the third. This system has proved satisfactory and necessary, because no man can stand permanent duty on orang-utan jungle work without 


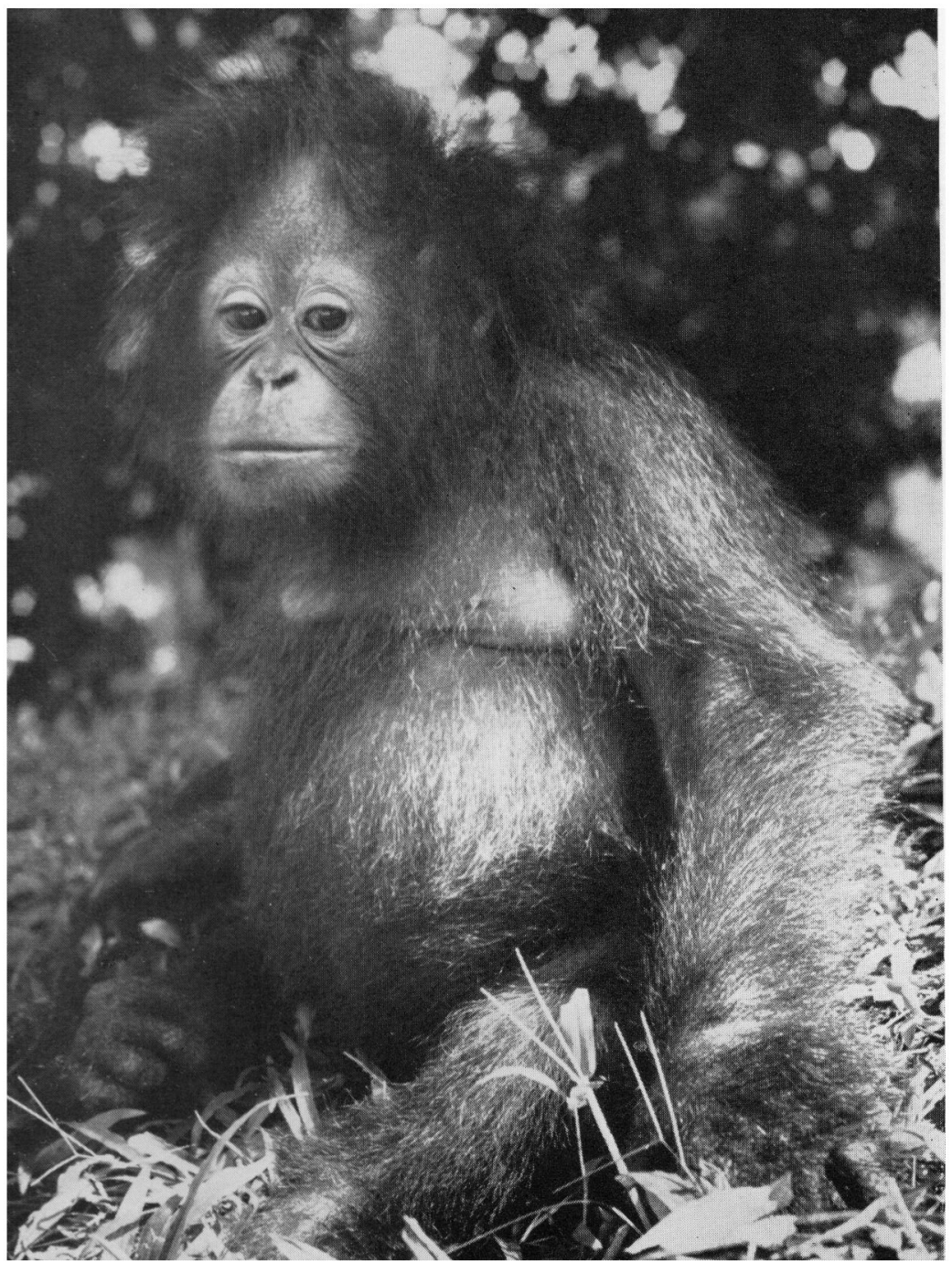

Photo: Sarawak Museum.

CYNTHIA (PHASE I) 


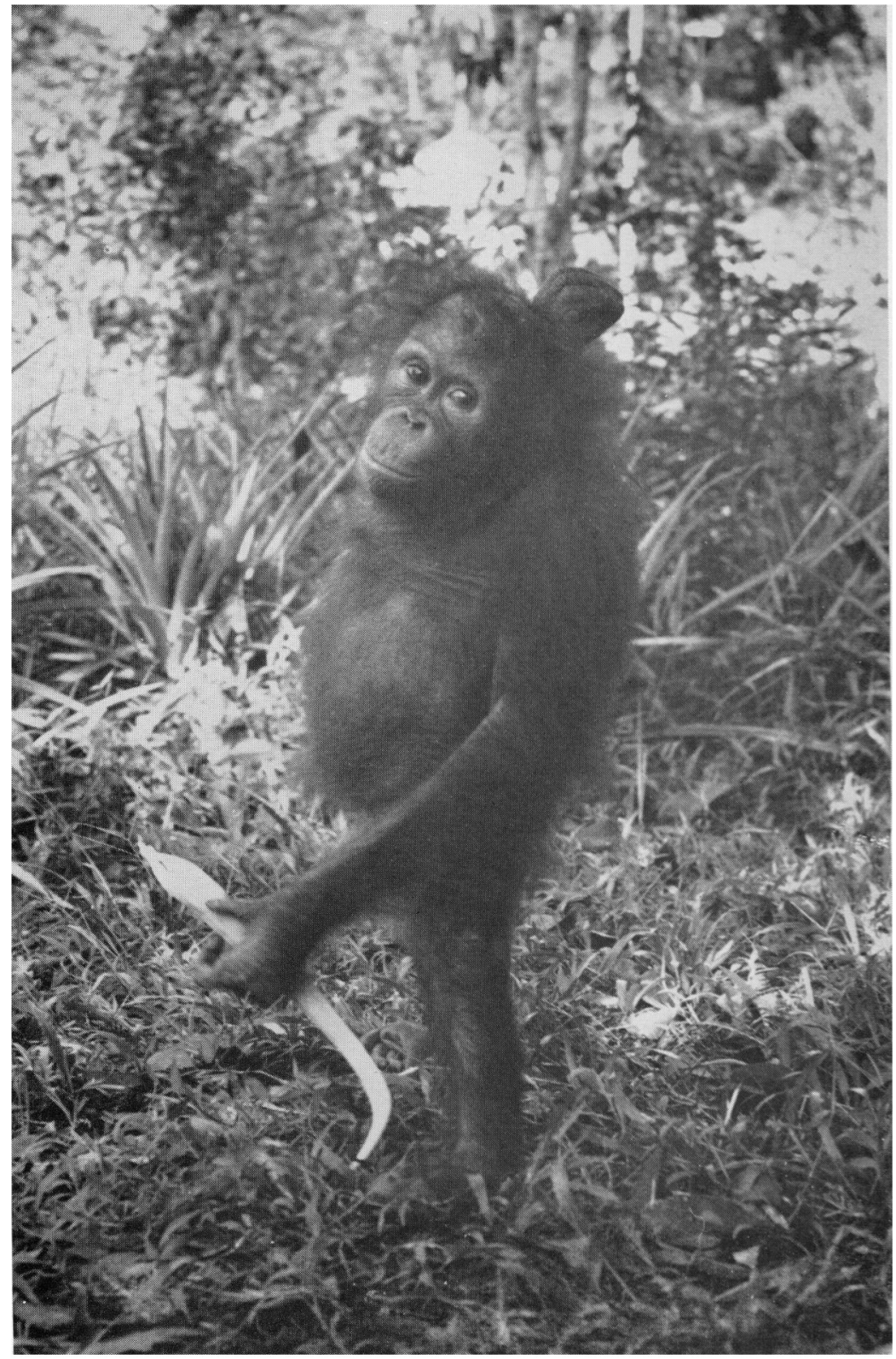

Photo: Sarawak Musetum.

\section{ARTHUR (PHASE I)}


becoming half of an ape himself as the months go by. There is no evening fun available at Bako Park; in fact, no social outlet of any kind. The attendants are under the eyes of the Senior Park Ranger at Bako, as far as daily working routine and personal needs are concerned. Supervision and direction of the project was otherwise centred in the Sarawak Museum in Kuching with prolonged and frequent visits in the Park for observation and checking of results by the writer.

Method.-The attendants were instructed to keep daily records of the animals' activities. In view of the low standard of education of the attendants these are simple accounts, written in Malay, giving information on distances covered, number of hours spent wandering in the jungle (in trees/on ground), meeting with other animals, spontaneous jungle feeding and so on. The records were checked regularly, anything out of the ordinary was questioned as soon as possible to get additional information.

The attendants were instructed not to interfere with the animals in any way, not to try to " teach" them skills or tricks, but to work with them, take them into the jungle and describe their activities.

Some extracts of these records are of extreme interest and a few are quoted below. Entries vary in terms of description in accordance with the writer on duty. They should be taken as true.

The attendants also collected specimens of jungle food taken by the orangs as far as this was possible. This work, continued over a longer period, will result in an impressive list, to be published later.

\section{The Animals}

Two young orphaned babies, male and female, were kindly given for the project by the Acting Conservator of Forests and Game Warden of North Borneo, Mr. P. F. Burgess. They arrived in Kuching by air on 24th November, 1961, accompanied by the following "case histories" :-

(1) The male. Later called Arthur.

"Origin: near Sandakan; it was probably bought by a Chinese from a Malay at Mile 18 in March, 1961, kept for four months and then given to Mrs. Byers who has had it since July. Its age is probably about two years. When the Chinese got it it had a scar on its forehead but was otherwise healthy and has kept well since then. It was released occasionally from its cage but did not roam far and returned for food. Its disposition is said to be placid."

(2) The female. Later called Cynthia.

"Originally captured by an Iban in the Kuamot region, Ulu Kinabatangan, in February, 1961, and kept since then by Mr. Mayhook in Sandakan. Age when captured about one year $\left(5\right.$ to $6 \mathrm{lb}$.). ${ }^{\star}$ It had a cold and round worms but was in fair condition and has been healthy since then. It was released occasionally, but did not stray far. It has a placid temperament."

[Letter dated 4th December, 1961, from North Borneo Forest Department to Conservator, Kuching.]

* It is unlikely that she weighed as little as that. Her age was probably just over a year at capture with c. 12 to $15 \mathrm{lb}$. normal weight. ${ }^{7}$ 
A third baby was "found" by an Iban Dayak of Sungai Assan and Sungai Rongan, adjoining the Naman Forest Reserve, 3rd Division of Sarawak, on 29th March, 1962. It was :-

(3) A male. Later called George.

"On the day mentioned at about 11 a.m. while having his break at the head of the rail line, ${ }^{\star}$ he heard something crying in the bush not very far from him. He became curious about it and went to inspect it. There he spotted a baby Maias (Orang-utan) which was crying bitterly not without emotion, as though it had lost its mother and desired love and protection. There was no sign of its mother seen around. He was moved with compassion and went nearer. When it saw him, it came towards him and embraced him warmly. He brought it home and without hesitation reported the matter. ..."

[Letter dated 3rd April, 1962, from Section Forest Officer, Sibu, to Conservator.]

This baby was given into Museum care by the Sarawak Conservator and Game Warden in early May, 1962.

Arthur weighed $30 \mathrm{lb}$. on arrival in November, 1961-which gave him an approximate age of $2 \frac{1}{2}$ years. ${ }^{7}$ His teeth and fur were in good condition but he had boils on the crown of his head and seemed too skinny. He had a deep scar over his forehead where he had received a heavy blow (probably at capture) from a sharp instrument, cutting right into the bone. The wound had healed perfectly but had left the animal with a curiously dimpled forehead. Blood and faeces were checked and remained without traces of parasites. Arthur gradually increased his weight to $43 \mathrm{lb}$. during the six months before his transfer into the enclosure at Bako.

Cynthia weighed $21 \mathrm{lb}$. on arrival in November, 1961, and was estimated to be approximately eighteen months old. She was in fine physical condition, with very light-coloured fur and a lot of "puppy-fat " round her chest. She was tested in the same way as Arthur and found healthy. She increased her weight to $29 \mathrm{lb}$. before transfer to Bako.

George weighed " about $8 \mathrm{lb}$." at capture in early April, 1962, and $10 \mathrm{lb}$. on arrival at Kuching on 9th May. His incomplete dentition indicated an age of ten months. His blood-test showed a peculiar type of malaria with which he had probably been infected through his mother, and for which he was successfully treated with a syrup-type of malarial antidote. His faeces were free of parasites.

Whereas the North Borneo pair had nails on the big thumb toes of their feet, the Sarawak baby had his thumb toes without nails. Both thumb toe varieties occur in Sarawak.

\section{THE EXPERIMENT}

The experiment was conducted in three phases, so introducing the animals to the challenge of freedom gradually and as they became ready for it. It was necessary first of all to get them used to living outside a

* A rail line for the extraction of timber only. 
cage ; this was done in a Kuching garden. Then, as they became stronger, it was necessary to introduce them to a transitional stage between captivity and freedom in order to adapt them gradually to rougher conditions, less human company and wide surroundings of green space. This was Phase II.

The third phase was the release to complete freedom from the enclosure as the animal became ready for it. At the time of writing, the two older animals, Arthur and Cynthia, have graduated fully to the third stage ; baby George is exercised outside the enclosure together with the older animals, but, at eighteen months old, he is still confined during noon rests and at night. This will go on until George shows signs of vigorous nestbuilding and independence.

\section{PHASE I-INTRODUCTION TO SEMI-WILDNESS IN KUCHING GARDENS}

The daily care and routine of the orangs in Kuching has already been described. ${ }^{7}$ After an early wash-down under the hose, their mornings were spent inside the cages mostly in play with fresh branches provided daily. Twice daily a variety of local fresh fruit and vegetables were given. Milk and some solids, such as biscuits, white bread and soft-boiled rice, were given three times-early mornings, midday and before sunset. Their afternoons were spent in the garden in free play in and around large fruit trees-durian, mangosteen, jackfruit and fig.

\section{(a) Physical Adjustments}

On 26th November, 1961, after two days in their new home at Kuching, Arthur and Cynthia were taken into the garden for the first time. Neither was inclined to climb the trees offered, which were mangosteen, out of the fruit season. Both played on the ground to an unusual extent for young orangs. Arthur showed delight and tremendous capacity in standing and walking a few paces, erect on both feet, throwing both arms up for balance. Cynthia's whole desire was to stay near her human friend Bidai. In any case, her hands and feet were unable to grip safely any tree or branch over 6 inches in girth.

An incentive was soon provided for Arthur to climb trees. He was put into a big jackfruit, loaded with fruit, easy to climb and in full view of the house. For three days he made no attempt either to stay and play within this tree or to eat any of the fruit, though he picked some and threw them down. As soon as the watcher (Bidai) left his position under the tree trunk, Arthur came down to the ground and followed him. Even barbed wire put round the tree-trunk to prevent Arthur's "escape" to the ground did not deter him from climbing down over it. Indeed, he showed keen interest in the wire itself, much more so than in the tree !

No attempt at nest-building * had yet been made by Arthur and a basic

* Nest-building attitudes are normally adopted at an age of about 18 months by which time Arthur had almost certainly already become a captive. All other youngsters who had become captive in Sarawak roughly at that age and had been brought up under the same conditions eventually made nests, but irregularly and with varying skill and intensity; apparently one inducement to nest-building is to have a companion, engaged in nest-building. ${ }^{8}$ 
desire to come down to the ground remained. This was probably accentuated by the fact that the only company available, Bidai and Cynthia, was on the ground below. Cynthia, although very much attracted by small branches overhead, was frightened at that stage in all larger trees, though she delighted to be on a high ladder. She gave the distinct impression that her fright had to do with insecurity of grip and a feeling of insecurity rather than being induced by vision. George, more independent at a much earlier age than Cynthia, delighted in high trees at eleven months old. But Cynthia would probably have been quite happy high up if only "mother" (Bidai) were sitting with her.

Three weeks after his first outing around trees in the garden, Arthur made his first nest-building attempt in the jackfruit tree. Next day he repeated in the proper manner, high up, very much exposed, working for over 30 minutes, stuffing the nest thoroughly with small branches picked and brought in from near larger branches. Again, a day later, he used the same nest, improving it by adding new branches. On that same day, Cynthia was observed for the first time inside her cage and during the morning arranging twigs and branches in a normal nest-building manner around herself in a circle while sitting in the centre, on a sack. Cynthia had no occasion to observe Arthur during his nest-building in the jackfruit tree, but she certainly saw him playing with his branches in a similar manner in his adjoining cage.

Arthur never showed any urge to remain in trees during night as other youngsters had before him ${ }^{8}$ or to actually use his nest for sleep. His followed a pattern of erratic and very occasional nest-building, apparently induced by availability of new trees, until his transfer to Bako six months later.

\section{(b) Emotional Response}

At first Arthur had to be caged separately from Cynthia because he tended to bully her, showing his strength and superiority in rough romping and wrestling. She responded by frequent whining in the baby manner, trying to get away from him, screaming hysterically as soon as Bidai ("mother") came into view, rushing to cling to him for protection.

When Cynthia first came to Kuching in November, 1961, she brought with her a small bathing towel which she continually draped around her neck or cuddled under her belly. At first the towel was only forgotten if Bidai sat with her. Replacements for the original, of different sizes and colours, were readily accepted and treated in the same way (as pseudocompanion or "fetish") when earlier specimens became battered and filthy. Very gradually, however, the towel was abandoned, mainly by help from Arthur-who regularly managed to steal it, poking through the wires of his adjoining cage, skilfully and patiently fishing with long fingers. She, on the other hand, became increasingly friendly with Arthur who could not bother her through the wire partition. They delighted in sitting opposite each other, poking through the wire, Cynthia tolerating Arthur's advances without trying to remove herself.

Although both Arthur and Cynthia were friendly with every member of the household, Bidai was the only person in full control of the animals. 
Arthur never attempted to bite his ankles in play, as he normally tried to do with all other known persons, with increasingly uncomfortable effects. Bidai communicated with Arthur by talking in a slow voice, gently guiding his teeth, hands or feet away from the objects he did not want him to touch, never attempting to smack him down. Cynthia gradually gave up the hysterical baby screams under Bidai's quiet care but retained a slow whining noise expressing disappointment when he left her.

Baby George, on his arrival in May, 1962, was housed and exercised separately for his needs were those of a baby of under one year old. ${ }^{7}$ There was also some danger of infection until his malaria had cleared up. He was nursed on special baby milk formula and vitamins. A few days before the transfer of Arthur and Cynthia to Bako, George was allowed to join them in trees during afternoon exercise for the first time. Whereas Arthur took no notice of him, just climbed and played in an adjoining tree, Cynthia showed close interest and spent several hours fairly high in the crown of a mangosteen playing with George and slightly (but not harmfully) bullying him. Although this was George's first experience in a high tree on his own he neither showed distress nor any desire to come down.

George was in fact very small for a transfer to the rougher climatic conditions at Bako, but it was imperative that he should join the experiment when he did because Cynthia was not ready to face release from the enclosure (Phase III) and had to be given a new companion as soon as Arthur went free.

In April, 1962, after the south-west monsoon had set in, bringing better weather with less rain, Arthur and Cynthia were taken to Bako Park by speedboat and then walked up to their new home in the jungle.

\section{PHASE II-TRANSFER TO JUNGLE SURROUNDINGS}

A wire-mesh enclosure, 24 by 40 feet and 13 to 19 feet high, was built on a slight slope (thus the uneven height; to allow for easy drainage of droppings and rain). It is clear on all sides but surrounded by jungle trees-well away from camp facilities of the Park. Built from hardwood meranti and belian timber uprights, it was equipped with four high sleeping platforms (Nests Nos. 1-4, cf. II (c) below), with an elevated wire-mesh feeding table, and with ropes and other incentives to exercise. Trees growing within the enclosure were left standing, but most small trees died soon owing to constant use in play.

Arthur and Cynthia arrived at Bako in the afternoon of 15th June, 1962. (George was taken there on 25th June.) They responded with tremendous excitement expressed in rapid locomotion, restless exploration of all aspects of the new surroundings, use of all available ropes, trees, etc., in an exuberant manner. During the following ten days this gradually slowed down. They were fed at the usual times by the attendants who walked up into the jungle to look after them.

\section{(c) Response to fungle Surroundings}

Between 16th and 18th June, the animals were observed closely, both within their sight and without their knowing it. At once a distinct difference between them became apparent. Whereas Arthur took a close interest 
in the jungle-world around the enclosure, Cynthia's main concern remained within it. He expressed extreme watchfulness at every sound and movement, and, if something new or curious occurred, he stood on all fours, either on the forest floor or on elevated parts of the enclosure, lifting his head towards the direction where the sounds or movements came from, mouth slightly open, lower lip hanging. He remained thus immobile until he had seen or realized exactly what was going on.

The forest floor was often investigated by haphazard digging with small sticks * or forefingers, lifting up small roots, etc., tasting earth. The game of wrestling or chasing along ropes and climbing equipment continued but only at certain hours of the day and in boosts-never at midday. Arthur remained at all times aware and watchful.

Of the first nine nights at Bako, Cynthia spent three on the forest floor and two with her companion Arthur in the same nest. Of four available nests she used three (all were built alike, but Nos. 3 and 4 were without roof cover until baby George arrived on 25th June); and on two nights only did she finally settle in her first choice. She had a tendency to get a last titbit of fruit in between making her first arrangements for the night and finally settling down. Arthur did not sleep a single night on the forest floor. He checked both on his human watcher and on his orang companion on at least three nights and seemed more relaxed in his attitude on his last three nights within the enclosure.

It became evident during later months when she had been partially released, that Cynthia had no inclination for building nests in trees, in spite of the fact that Arthur by then built his mostly in full view and spent all his nights in them. Cynthia, who was regularly released in the late evenings from July, 1962, onward in order to encite her to build nests and spend the nights outside the enclosure, waited (and sometimes whined) for the enclosure door to be opened for her when she was ready for sleep. Increasingly, she spent her nights on the damp forest floor inside the enclosure.

This amazing development should not be speculated upon within the context of the enclosure. Further observations are required of Cynthia's behaviour during Phase III (see also III $(k)$ below).

The animals were deliberately left undisturbed for long daylight periods during the first ten days in the enclosure, in order not to give them too much human interest. On the third day it became apparent that Arthurapart from his constant watchfulness-got rapidly bored, seeking outlets in "silly" amusements and in walking up and down or sitting on that side of the enclosure from which human attention and entertainment would presently come (the approach path uphill, through the jungle).

Cynthia's interests remained centred within the enclosure. She soon got over her initial fear of "being left behind" expressed in hysterical baby-screams when the attendants left after feeding.

Baby George's response was still more self-centred than Cynthia's and quite in accordance with his age. He was slightly excited at the new surroundings, delighted at his playmate Cynthia, distressed at her bullying

* This " tool using" is the subject of continuing study ; for a later report, see also III (i) below. 
him; and he expressed the essential need for continued presence of a " mother" for prolonged periods.

It was therefore decided to release Arthur on his own at first, and to let his younger companions follow when they became ready.

\section{PHASE III-RELEASE TO FREEDOM}

Arthur was released on 25th June. A new feeding platform had been built for him on top of the enclosure with easy access from the forest canopy by way of a tall jungle tree growing through the wire-mesh ceiling.

\section{(d) Minute-to-minute Account of the Day of Release, Taken from the Author's Diary.}

Time.

Action.

2.00 p.m. Door opened.

2.10 After prolonged hesitation Arthur goes out and climbs up along door and high tree next door, into forest canopy.

2.10 Moves slowly in trees in direction of path whence so far all human approach came. Two watchers follow all his movements on the forest floor below. He slowly comes down into lower canopy about 20 feet off the ground. One hour took him about 200 yards away from enclosure.

3.10 Watchers are ordered to move back to the enclosure and away from Arthur, leaving him behind. Arthur at once follows behind watchers rapidly, slowly whining (he has not done this for some months).

3.30 Bidai is told to sit on top of enclosure near new food table in order to show Arthur where he can get his food. Bidai shows him turtles' eggs, his favourite titbits. Arthur comes down to him twice, each time taking an egg.

4.00 Bidai is told to go back to camp in full view of Arthur to see if he follows. Arthur whines high in a tree and starts to follow Bidai, but remains within 150 yards of enclosure, as if "on guard". However, he does not return close to enclosure in spite of the fact that the new baby, George (whom he has not yet met properly), whines inside.

4.20 Returns to enclosure moving in high canopy. [Note-Cynthia has no interest whatever in Arthur's movements.]

4.25 Kra monkeys (Macaca irus) calling near. Arthur replies (or seems to reply) with loud smacking noise. He does not repeat this after Kras repeat their own call.

4.30-32 Smacking noise; rattles high branch. Repeated smacking, also tries deeper, more throaty noise.

4.35 Door to enclosure is reopened to see if he shows any desire to return into it.

4.37 Arthur inclined to come down, moving slowly. Cynthia playing with open door; Kra calling.

4.45 Arthur breaks large dead branch on tree near enclosure and throws it down (nearly right into my camera).

4.50 Comes down on top of enclosure, takes food and goes up tree.

4.52 Throws dead branches on to enclosure from tree, blowing "raspberries", smacking lips. Cynthia still playing with open door on ground; no attempt to join Arthur or even to leave the enclosure.

5.10 Arthur in difficulty to step over from one tree to next in high canopy. Tries hard to reach with toes and fingertips in various positions. Eventually swings over only after balance and grip completely secure. Cynthia takes long drink of milk from my hand near door and goes back into enclosure to play with George.

5.20 Arthur busy breaking and throwing branches down, about 50 yards away, near path. 
Time.

5.30

5.33

5.40

5.42

6.00

6.05

6.10-18

6.21

6.25

6.27

6.28

6.29

6.30

6.45

6.50

7.00

7.15

8.00

Action.

Bidai returns with Arthur's evening food and goes on top of enclosure. Arthur immediately joins him there.

Arthur takes milk from Bidai.

Arthur goes up tree. Baby George is fed inside and helper goes back to camp. Arthur follows in trees about 30 yards away "seeing him off",

Throwing down dead branch from high tree near. This one is a tall coniferous tree which must have a good look-out over some distance.

Two Proboscis monkeys try to settle for the night about 200 yards away in medium-sized trees. They do not call but make themselves conspicuous by jumps in trees.

Cynthia settles in Nest 1.

Arthur, still on same high coniferous tree as at 5.42 p.m. and near Proboscis monkeys, continually throws branches, rattles crown, blows raspberries - then, once only, howls in a terrifying manner with alternate grunts. This was never heard from him before. It is surely intense excitement and distinct attempt at frightening off the Proboscis pair by display of strength. Indeed I hear two jumps immediately following the howl. He has certainly succeeded in chasing them away from the enclosure. Then he moves back towards enclosure.

Blowing raspberries.

Apparently still watchful of Proboscis.

Arthur looking down at me from high up, as if "checking".

He moves down and comes on top of enclosure.

Moving down further and on to forest floor (once more " checking" ?).

Climbing up tree.

Climbing towards path, sitting high, watching.

Bidai going off, back to camp. Arthur takes no notice, remains sitting, watching. Bidai calls him (to see if he can be induced to come back into and sleep inside enclosure); he takes no notice.

On same tree, watching.

Ditto. Just sits on high tree, about 30 yards away from enclosure. N.B.-No attempt at nest-building.

No attempt at returning.

N.B.-It rained through four hours of that same night but Bidai found him next day (26.6.62) still on same place at 6.30 a.m. He took drink and food readily from him and came to get it on to the top of the enclosure.

Arthur consistently remained in close contact with the enclosure during the next day and never ventured farther than 300 yards away from it. He was increasingly attracted by what went on at or in it, rather than by the jungle world round about. It became evident that he would require tuition to explore and make a living in the jungle-world. He seemed lost on his own and away from the enclosure, not knowing what to do.

\section{(e) Education to Wander in Trees; Acquisition of Territory.}

Regular hours were spent over the following months in taking Arthur into the jungle, returning to the enclosure only at feeding times. Very gradually he increased his knowledge of the forest and during the first week got to feel secure within roughly $\frac{1}{4}$ square mile of the enclosure. He stuck to it closely, however, if no incentive was given him to wander, i.e. if nobody called him to follow.

In going away from the enclosure and into "unknown territory", 


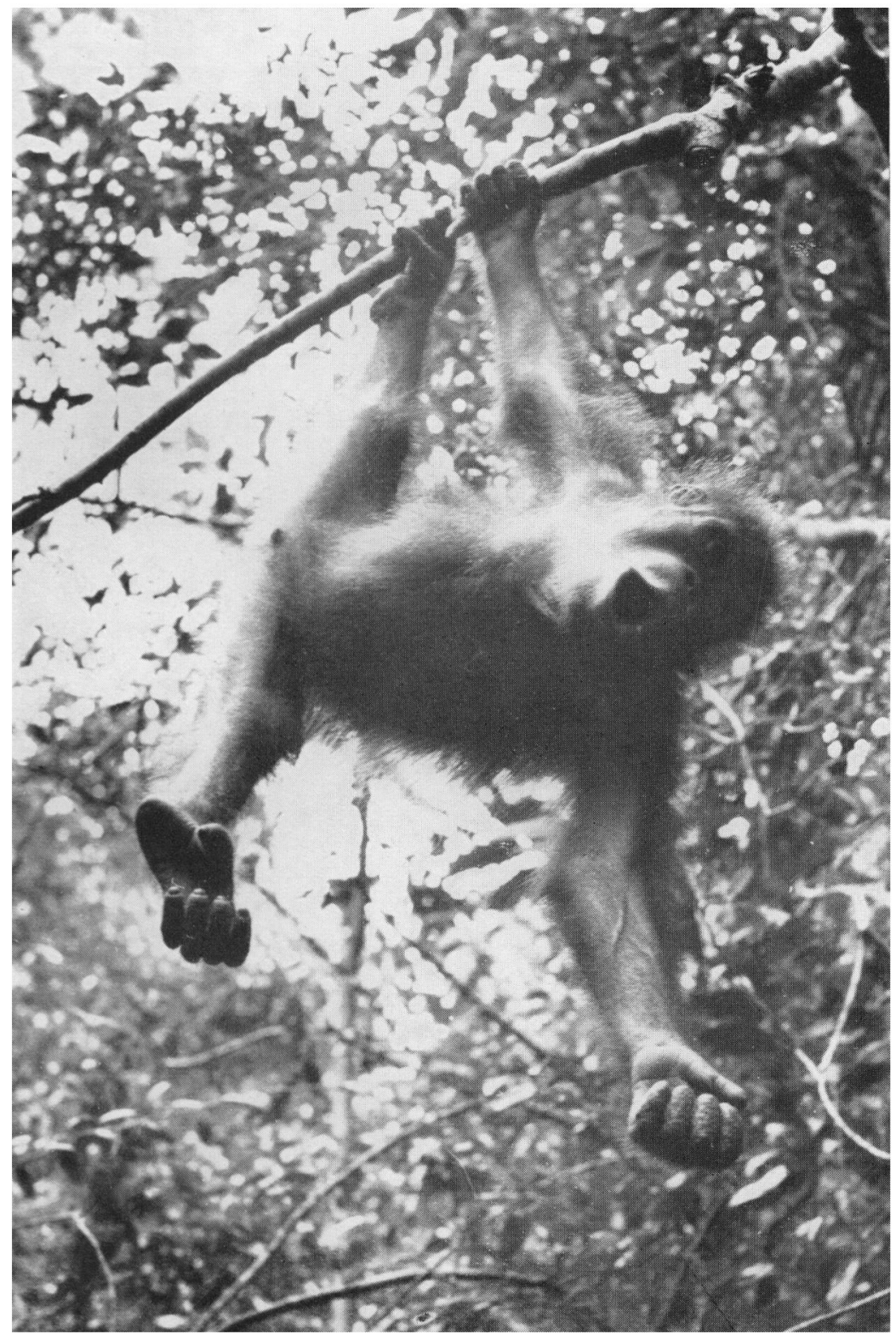

Photo: Sarawak Museum.

ARTHUR (PHASE III) 


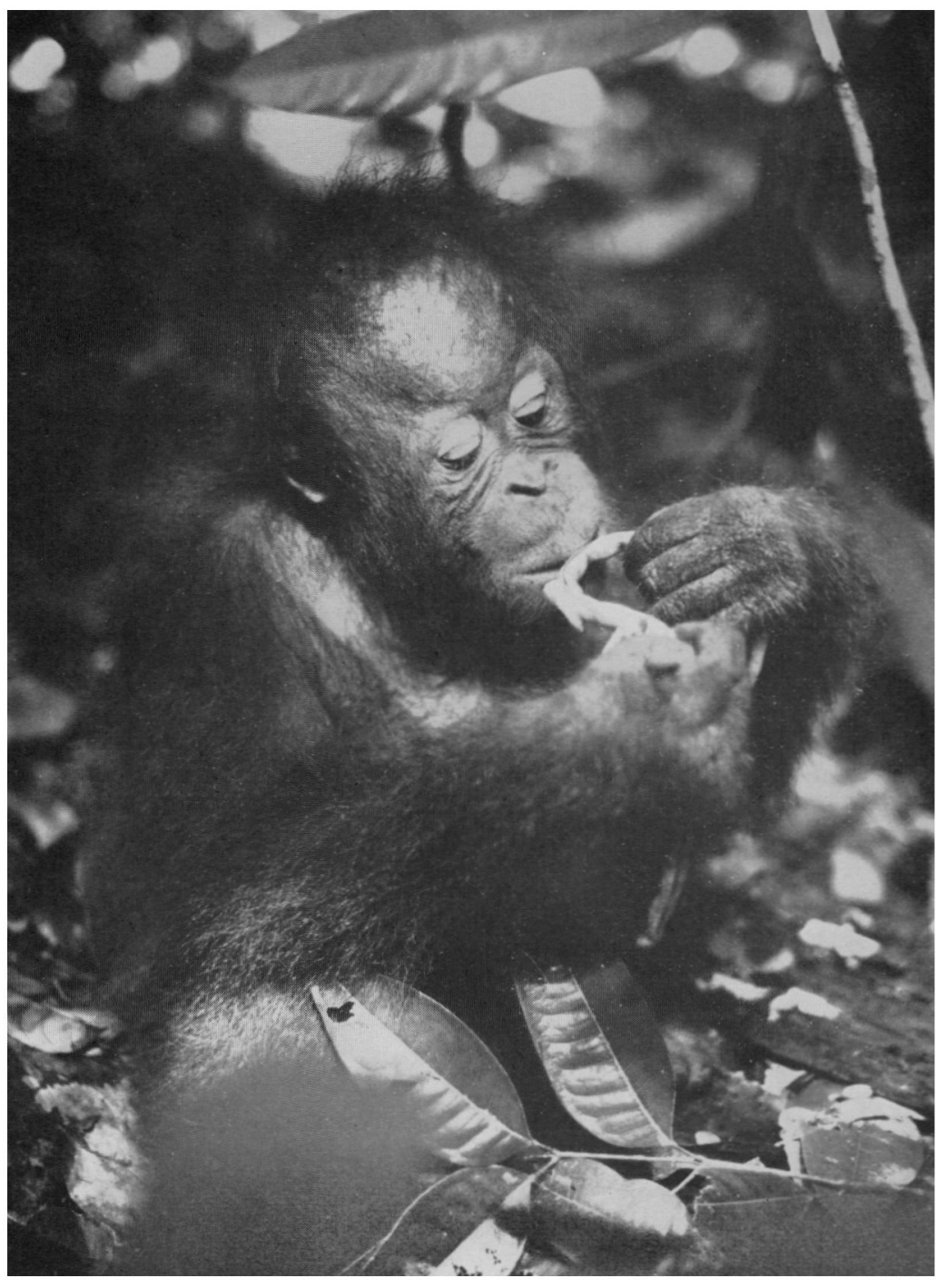

Photo: Sarawak Museum.

GEORGE AT TWENTY MONTHS OLD 
Arthur was very careful not to lose sight of his man tutor. Human progress on an uneven and pathless rain-forest floor, agonizingly slow by human standards, was too quick for a young orang-utan to be able to follow in trees alongside. Until we found the slow-speed type of walk suited to Arthur, which meant going at normal speed for roughly 50 yards and then sitting down fully ten minutes or so, he simply came down to the forest floor to follow speedily behind on all fours, dog-like, frequently turning his head to have a look behind! Only if enough time was given him to proceed in trees did he in fact take to trees, mainly chosing the lower canopy to move in, occasionally climbing up into interesting crowns of higher trees-and then a full 10 minute rest was required.

Arthur was often anxious lest he lose his tutor, and came down to the floor to sit near him for some time doing nothing except for an occasional invitation to play. Only if his tutor would stay-put, refusing to play or move, did Arthur decide to take to the trees once more.

When wandering as a tutor with Arthur and at orang speed, it was astonishing to see how quietly he was able to move in trees. Indeed, it was easy to lose him without constantly looking up. He was never seen jumping. In moving, his eyes guided the touch of his fingers and toes, with limbs and body following in slow, deliberate balance and adjustment, swaying. Some of his antics were extremely noisy indeed, but always deliberately so, expressing exuberance or apparently the wish to impress or display strength.

After nine months of freedom, his territory included roughly 2 square miles.

\section{(f) Interests and Behaviour on the Forest Floor and in Caves.}

In coming to the forest floor Arthur was inclined to keep his tutor company, sitting with him and ragging him. But sometimes he pursued special interests of his own there, too. He took various and very close looks and drank at the small rocky stream, full of boulders, that runs below the slope near the enclosure. His way of drinking was to either bend down on all fours at a shallow pool, sucking water in, or to sit near the edge of the water and, with a quick scoop of the open hand, flick it into his face and over his head. If water was splashed over him from a pool, he was delighted and opened his mouth wide to receive each new spray. He also liked to shove through shallow water on all fours, wiping hands and feet on underlying rocks and boulders, though he never attempted to submerge his body.

Identical attitudes were later observed in Cynthia and George.

Arthur went inside small, cave-like shelters of sandstone rock, numerous in the vicinity, and often sat for some time in these. He rolled and lay in them and dashed into corners and crannies, as if exploring; once he stood on all fours, slowing turning in a circle-an attitude otherwise associated with nest-building.

These delightful antics continued during later months but appeared less pronounced once a cave or shelter had been explored and was only revisited.

Chewing of pebbles, earth-eating and the smearing of earth over the 
face was regularly observed in all three animals. That this was done in caves is not necessarily significant: it was seen elsewhere. But the interesting fact remains that caves were a prime incentive for Arthur to come down from the trees. Lying down and collecting leaves, exploring of all cave aspects and general nest-building movements, however, suggest more than curiosity and play. They are expressions of deliberate homemaking interests. Further observations of this kind and parallel records of wild orang-utans may well provide valuable suggestions for new interpretations of orang-utan remains in prehistoric caves in South China, Indonesia and elsewhere. ${ }^{9}$

Caves and shelters were also used extensively for protection from rain, both by Arthur and Cynthia, specially during the monsoon season, from November, 1962, to February, 1963.

\section{(g) Nest-building in Trees.}

On the second evening outside the enclosure Arthur made his first nest, immediately after taking his evening milk at 6 p.m. He climbed up a high tree and built the nest so quietly that it was uncertain until daylight whether he had indeed built one. But the nest was clearly visible next morning with Arthur himself in it-after taking fully five hours' torrential downpour during the night. He used the same nest the two following nights, each evening improving it slightly by stuffing it with a few new branches. Then he built a new one. During the next fifty days he built altogether fifteen nests-all within sight of the enclosure.

Once he was observed building a nest to shelter in from rain; it poured heavily at 7.15 a.m., which is no time to nest, normally. He also seemed to shelter under his nests from rain. A representative entry in the diary says :

" 23.9.62 : Arthur was hanging under his nest because it was raining."

\section{(h) Sounds.}

When, during his wanderings with his tutor, Arthur heard whining or other orang sounds he was inclined to return to the enclosure and get into contact with his companions. He did not answer such calls but remained watchful and immobile for a moment until the noise was over. On returning from an outing one day he suddenly started a loud noise produced by smacking of lips (one can imitate it to some extent by kissing the back of one's hand, noisily) and ending in raspberry blowing. This noise was produced about 200 yards away from the enclosure and at a point where he possibly came first in sight of it (there was no other disturbance or anything else visible anywhere which might have caused his response); and perhaps meant a greeting. Once, on hearing quiet human approach through the undergrowth, without being able to see anybody, Cynthia produced a deep, loud grunt-bark-much more of a bark than Arthur's grunts. Probably this was a new warning noise or perhaps the expression of assuming the role and responsibility of a leader in Arthur's absence.

A variety of similar sounds were uttered on meeting other animals, but most pronounced, particularly during the first few months of wandering into unknown territories, were Arthur's distress signals, high-pitched 
whines. As he gradually extended his territory, these whines were less frequently heard and were only given if he found himself lost and alone.

(i) Spontaneous fungle Feeding.

A prolonged study of wandering and feeding habits of all three youngsters will be required before the problem of how to educate them to self-sufficiency can be successfully tackled. It is quite clear that the jungle itself gives sufficient incentive to feed, but that roaming and wandering is absolutely essential to enable the animals to pick up what they need. As long as they are based on the enclosure they will naturally be inclined to return to fruits and other goodies provided for them there at set times.

However, the enclosure must remain an essential feature until George graduates from the baby-phase. That is until he is able to proceed on his own from tree to tree and until he builds nests properly. Once he is old enough for these tasks it will become easier to teach the group as one unit, by taking them into different sections of the territory each day and forcing them to stay overnight away from the enclosure.

In the meantime, a number of botanical specimens had been collected of natural food spontaneously taken by the animals in the course of their wanderings. This is by no means a complete list, but represents what the attendants were able to collect. Much of their feeding takes place high up in the crown of trees where exact observations are impossible. A list of these natural foods, as identified by the Forest Botanist, is now slowly growing. It will be published later.

The bulk of natural orang food is, of course, fruit from trees. It will be important during the later stages of the experiment to try to guide the animals' wanderings to such fruit trees which are spread over wide distances at Bako. A previous intensive study which was made of the flora ${ }^{6}$ will greatly assist these operations.

It became evident, however, that a jungle space not only holds a rich flora, but much other feeding interest as well. For instance, all three orangs have daily been observed investigating ants' and termites' colonies in trees and on the forest floor, taking up to 20 minutes of scraping, poking and biting into one, consuming the live contents with gusto. Sticks and twigs are used for this purpose, too, though not in exactly the way as observed by Jane Goodall for wild chimpanzees. ${ }^{10}$ The orang's approach is a more direct one, with a variety of methods adopted " on the spur of the moment" without apparently much preconception of their ultimate effectiveness.

Much activity, because it takes place in the forest canopy, cannot be observed clearly; for instance, the robbing of nests of birds and small mammals. In this, as in many other instances, whether in fact live food was taken from the nest was not detected, but in view of the orang's tendencies to test and taste everything at least once, it is likely that young birds and mammals are taken as special titbits in this way; eggs go as a matter of course.

Arthur's tendencies to go regularly for colonies of stinging bees established in cliffs near the enclosure were much of a bother. How he found 
their abode and what he did to them and their produce was never discovered, but on 25th August Arthur demonstrated to me direct that he not only took an interest in the bees' homes but also in the bees themselves :-

" 25.8.62 : Went to join Arthur in the jungle near enclosure for observation. Hot afternoon. Sat for some time on the forest floor resting. Sudden attack of wild stinging bees. Wrapped raincoat round head for protection. Arthur-whom I had previously ' lost' and who must have caused the attack - came to sit with me under the raincoat. But he soon got tired of the game and started to peep out, thereby letting in the angry bees. Bees stang me on head and face and Arthur picked them out of my hair, put them in his mouth and consumed them! Then there was nothing but to run for it with Arthur in the wake!" [B.H. entry.]

\section{(j) Meeting Other Animals (Including Snakes).}

Arthur's first encounter with Bako's most spectacular monkey, the Proboscis (Nasalis larvatus), on the day of release from the enclosure has already been described. On this occasion he gave a spontaneous display of strength. On later occasions this was less pronounced. It seemed as if, once the " peck-order" was established (? by "trial-and-error"), it became less important to make a fuss.

The numerous and much less shy long-tailed Kras (Macaca irus) were often attracted by fruit on top of the enclosure. They even dared to step on to it-if Arthur was away from home.

But whereas Proboscis deserved Arthur's attention, it seemed as if he took the Kras' inferiority for granted, not bothering much about them.

A more humorous mood prevailed when Arthur came upon an adult male civet (Paradoxurus hermaphroditus) which, although brought up in captivity, found no difficulty at all in adapting itself to wild living at Bako:-

“6.2.63 : It was raining. We found Arthur at 8.40 a.m. quarrelling with the civet we set free some time ago (12.11.62). He managed to bite the civet's tail but seemed uneasy when he was subsequently chased by it. He climbed a high tree where the civet could not get at him."

There are two records of meetings with snakes. The first concerns Arthur-it happened on

“ 12.7.62 : As we walked again, he saw the water I carried. He took it and drank some. Then he poured the rest over his head as though he was taking his bath (!). Then we walked again and we spotted a snake near a rock. As Arthur saw it he tried to catch it but it was too late and the snake escaped into a hole."

Bidai, the author of this note, was questioned on the incident a few days later. He said the snake in question was black, about 4 feet long, that Arthur had taken a twig from the forest floor, had chased the snake and hit it with that twig. Bidai himself had stood by without interfering as he was instructed to in the event of meeting other animals. He said he had been uncertain what to do, because he thought the snake was a poisonous one. There were no eye-witnesses here, but there is every reason to believe the story. 
The second encounter, which happened in the presence of Life photographer L. Burrows, concerned Cynthia and took quite a different turn :-

" 25.10.62 : Cynthia, who had climbed a low tree near the enclosure to a height of about 15 feet, suddenly fell off this tree. She crashed down to the forest floor, lay with all fours outstretched, shocked and winded. As I bent down to see if she was hurt, I saw a small green tree-snake (Trimerusurus wagleri), deadly poisonous, curling in threatening attitude 2 feet away from us." [B.H. entry.]

Now this was the first (and so far only) time when any of the numerous orang youngsters which we had looked after over a decade had ever fallen off anywhere. Even small babies only climb where they feel secure. The solution is, of course, the snake. This, a tree species, had not been there on the forest floor before Cynthia's fall. I should have seen her because I had been sitting very close for some time. The snake must have been curled in the tree Cynthia had been climbing, and her reaction was to let go. She had not been bitten. But she lay shocked for several minutes and spent the rest of the afternoon inside the enclosure lying on her belly. Arthur became fascinated by the killing of the snake. Neither he nor Cynthia showed distress when the dead specimen was shown to them at close quarters.

\section{(k) Social Needs with Special Reference to Individual Difficulties of Each Animal to Adjust to "Normal" Patterns of Development.}

As mentioned in the Introduction, our three young orangs are not an " ideal group". Arthur, just under four years at the time of writing, a keen adolescent, has rapidly grown too strong to be able to match himself against his human companions. Cynthia, a year younger, remains frightened of his attempts at wrestling competitions. Baby George, still in need of mothering, gets many incentives and much tuition from his older companions. His process of growing up will probably be easier for he will be able to rely a great deal on the older animals and gain confidence without the near presence of a human "mother".

\section{Arthur.}

Observations of Arthur's development over the past nine months clearly demonstrated the animal's social needs. His tendencies towards wild living patterns were much geared to the individual proficiency of the attendant on duty. During the months of August and September, 1962, for instance, his urge to explore and wander increased and he extended his territory to about 2 square miles, in spite of the fact that his ape companions were still confined to the enclosure or its immediate vicinity. Only in heavy rain did he refuse to wander.

During September, 1962, however, the senior attendant (Bidai) had to be relieved to go on leave and a second attendant went sick. The job of teaching Arthur was left to two less experienced men. At the end of the month it became apparent that Arthur had lost his urge to go away from the enclosure. He did not follow the attendants' calls but increasingly sought outlets in "silly" amusements in the immediate neighbourhood of 
the enclosure, including the "lying in wait" near the main path, for unsuspecting visitors, in order to accost them.

The situation was easily remedied by reinstating Bidai to the job and by releasing Cynthia from the enclosure for longer periods. Soon Arthur reverted to his old exploratory interest; once it even looked as if he dared to do more than that for he was "lost " during a whole day and one night which he spent far away. However, he did not do so again. Perhaps the experience had not been entirely satisfactory-perhaps something disturbed him-there is no way of knowing.

Soon after, he slowed down again. This time because Cynthia was in need of coaching. She had refused to acquire jungle interests of her own accord and the best way was to take George away from the enclosure, thus inciting her to follow. This method had the desired effect. But in consequence, Arthur gave up his solitary explorations : it was more fun to stay with his companions. Unfortunately human visitors there continued a prime interest-and it seems a losing battle to try to teach Arthur that he must not get into physical contact with them. He understands perfectly what is wanted, but cannot help himself.

\section{Cynthia.}

Cynthia's early background and her pathological attachment to terrytowels has already been described. Afterwards she became emotionally tied to Bidai, who had been looking after her full-time, before her transfer to jungle surroundings. When Arthur was fully released, she was still too small to be coached alongside him and she remained in the enclosure for one month. Then she was released during Arthur's wanderings and in the evenings before darkness.

But at the beginning of November, 1962, when Cynthia was $2 \frac{1}{2}$ years old and still showed no inclination to wander or build nests, it was decided to try to force the issue by excluding her permanently from the enclosure and by taking little George along pick-a-back on the daily wanderings with Arthur.

For one day only she stayed behind while Arthur and George went off with the attendants. On the second day and from then on she followed readily. She acquired an interest and got used to the territory around the enclosure, behaving in much the same way as previously described for Arthur.

At the time of writing, Cynthia still builds no nests. Even outside the enclosure, where a sack could no longer be given to her for additional comfort because Arthur would invariably have stolen it, she preferred to sleep on the ground. Sometimes, especially during the rainy season, she was found in the early mornings nesting on top of the enclosure.

This lack of interest in nest-building and preference for sleeping on the ground is very surprising indeed. An explanation or interpretation is not attempted at this stage; further observations on all three animals are necessary.

Cynthia looks healthy and fit, chubby rather than skinny, although she has not gained weight quite sufficiently during the nine months following her transfer to Bako. She is good-natured, reserved and cautious, and 
still prefers Bidai to all other attendants. But she is no longer emotionally dependent. She prefers the companionship of George to that of Arthur whose superior strength she respects. She remains detached and selfcentred throughout.

In comparing Cynthia to Arthur, one might say she seems mentally retarded. But here the matter rests. For it is quite possible that this state of affairs conforms to normal development, and that females must display less brainpower in order to live and compete successfully with the male.

\section{George.}

George was transferred to Bako at the time of Arthur's release from the enclosure (25th June, 1962) only with reluctance because he was under a year old, still fully dependent on baby-care. But from the very beginning he gave us no trouble and developed splendidly. He showed much independence, early curiosity in his surroundings and great keenness to join in during jungle outings at eighteen months old.

He was carried at first, but every time the attendants sat down to give the older orangs time to catch up or play in trees, he also took to the trees wherever he could. He now knows that if the attendants get up it does not necessarily mean they will disappear from sight. He comes down from the trees if they call him, or to take food and titbits from them, en route. $\mathrm{He}$ has shown the first signs of nest-building attitudes and has grown a thick fur during the monsoon months. $\mathrm{He}$ is keen to play with Arthur, who respects his inferior strength, and is very friendly with Cynthia also.

\section{(l) Health.}

Since transfer to Bako, the animals have never been ill. The beginning of June was chosen as the best time for tranfer because this is the full summer (musim tedoh, south-west monsoon) with much calm weather and sunshine. In this way, a gradual acclimatization to rougher, exposed conditions was possible. But even during the months of December, 1962, January-February, 1963 (north-east monsoon), when extreme bad weather prevailed causing disaster floods elsewhere in the country, the animals suffered no ill-effects. Twice during this time a slight cold was noticed in Cynthia, perhaps through sleeping on the soaked jungle floor; but it was cured by a day and night's stay in the enclosure, the comfort of a sack cover and a couple of Aspirins.

Once for several days during the summer Cynthia suffered from a skinitch, mostly on her hands and feet. The cause of this was not detected. It is possible that she had been in touch with poisonous trees, some of which are known to grow in the vicinity of the enclosure. She was taken to Kuching to the veterinary clinic and given Vitamin D and a bath in lukewarm water. It was interesting to note that the animal was perfectly clean, although she had not had a bath for over a month. The itch subsided after treatment.

All three animals fed well over the entire period. Arthur gradually decreased his milk intake of his own accord. Increasing amounts of natural foods, in addition to the imported rations of varying fruits, vegetables and biscuits given by the attendants, were consumed. 
Under Bako conditions, weights could not be checked monthly. Eight months after transfer, on 22nd February, 1963, a check gave the following results :-

\begin{tabular}{|c|c|c|c|c|c|c|}
\hline & WEIGH & $\begin{array}{r}\text { INCREASI } \\
\text { (Weigl }\end{array}$ & $\begin{array}{l}\text { ORANG-U } \\
\text { in English }\end{array}$ & $\begin{array}{l}\text { TTANS AT } \\
\text { lb.) }\end{array}$ & IKo & \\
\hline & $\begin{array}{l}\text { Date and } \\
\text { estimated } \\
\text { age. }\end{array}$ & $\begin{array}{l}\text { Weight. } \\
\quad l b .\end{array}$ & $\begin{array}{l}\text { Date and } \\
\text { estimated } \\
\text { age. }\end{array}$ & $\begin{array}{l}\text { Weight. } \\
\text { lb. }\end{array}$ & $\begin{array}{l}\text { Date and } \\
\text { estimated } \\
\text { age. }\end{array}$ & $\begin{array}{l}\text { Weight } \\
\text { lb. }\end{array}$ \\
\hline thur & 24.11 .61 & & 15.6 .62 & & 22.2 .63 & \\
\hline nthia & $\begin{array}{l}2 \frac{1}{2} \text { yrs. } \\
24.11 .61\end{array}$ & 30 & $\begin{array}{l}3 \text { yrs. } \\
15.6 .62\end{array}$ & 43 & $\begin{array}{l}3 \frac{3}{4} \text { yrs. } \\
222.63\end{array}$ & $56^{\star}$ \\
\hline & $1 \frac{1}{2}$ yrs. & 21 & 2 yrs. & 29 & $2.3 \mathrm{srs}$ & 32 \\
\hline & & & 10 mths. & 10 & $1 \frac{1}{2}$ yrs. & 22 \\
\hline
\end{tabular}

* This may not be accurate within 2 to $3 \mathrm{lb}$. Arthur resisted the operation of being weighed in my arms, on a bathroom scale brought from Kuching.

\section{CoNCLUSION AND OUTLOOK}

The pressing need both for information on normal living patterns and for immediate rescue of a few young orphaned orang-utans locally, instigated the experimental project described. One year's experiences clearly demonstrate that :-

(i) Young orang-utans re-adapt themselves to wild living patterns.

(ii) This process is slow and in gear with the individual animal's age, temperament and need for companionship and guidance, i.e. his social needs.

(iii) The arboreal parent can be replaced to a certain extent by a terrestrial human tutor.

The basic curiosity of a young orang in its natural surroundings incites the animal to acquire skills necessary for survival (acquisition of territory, food-gathering) to a high degree of proficiency, by trial and error. However, the incentive to do so must come from a parent (or tutor, in our case) at a certain early age, and learning takes several years.

The young orang is ready to take an interest in the outside world at the age of one. He then remains under guidance of a parent for at least three years. He reaches maturity and full proficiency at ten years old. Evidently our Bako animals are much handicapped by the absence of an arboreal parent. Their progress may therefore be slower than normal. But if their development is closely guided for a number of years, and perhaps to maturity, invaluable data on a great variety of problems will be obtained. This, a complex research project, cannot be tackled with the present organization.

From the point of view of conservation, it is demonstrated that, if repeated in a protected Wild Life or Nature Reserve containing a population of wild orang-utans, a similar project-adequately staffed and financed-might well save a score of orphaned youngsters which would otherwise perish. 
Such a Reserve must be created now and closely protected, as a first step. International co-operation and guidance is urgently needed to press the issue.

\section{LITERATURE}

1. Bruen, D. L., and HaIle, N. S. " Report of the Maias Protection Commission, 1960." Government Printer, Sarawak, 1961. (A Sarawak Government Census of wild Orang-utans, in Sarawak.)

2. Schaller, G. B. "The Orang-utan in Sarawak." Zoologica, 46, 2, September, 1961.

3. HARRISsON, B. "Orang-utan : what changes of survival ?" Sarawak Museum fournal, X, 17-18, 1961.

4. Rowel , Th. "Preservation of wild life and zoos." Nature, 196, 4860, 1963.

5. HARRISSON, B. "Report on recent investigations in North Borneo on behalf of the World Wildlife Fund" (a census in sample habitat areas of N. Borneo). In press.

6. BRUNig, E. "An Introduction to the Vegetation of the Bako National Park." Report of the Trustees for National Parks, 1959-60. Government Printer, Sarawak.

7. Harrisson, B. Orang-utan. Collins, London, 1962.

8. HARRISSON, B. "A study of Orang-utan behaviour in semi-wild state, 1956-60." Sarawak Museum fournal, IX, 15-16, 1960.

9. KAHLKE, H. "Wo and wann lebte Gigantopithecus?" Natur und Volk, 91, 1961.

10. NAPIER, I. In " Early man and his environment." Discovery, XXIV, 3, 1963 describes Goodall's observations (incl. photographs). 